\title{
Autenticitetsstrategier i Triers trilogier - Om at skabe affekt via effekt
}

\author{
Af Heidi Philipsen
}

\begin{abstract}
I denne artikel anskueliggores, hoorledes forskellige filmiske strategier kan medvirke til at formidle autenticitetsfølelser til tilskueren. Artiklen diskuterer desuden ud fra eksempler, hoorledes filmisk autenticitet kan indkredses ved hjalp af Jay David Bolter og Richard Grusins begreber 'immediacy' og 'hypermediacy'. Der argumenteres for, at der eksempelvis i film af Lars von Trier eksisterer et langt mere komplekst forhold mellem disse to begreber, end det anskues $i$ Bolter og Grusins bog, Remediation. Men at begreberne fra denne bog kan medvirke til at kvalificere diskussionen om og forskning $i$ autenticitet, bl.a. $i$ nye film. Autenticitet, eller immediacy, optreder $i$ Triers varker side om side og synes nermest at betinge hinanden. Iser filmen Idioterne (1999) analyseres i narvarende artikel som en film, der rummer en kompleks og sardeles iscenesat form for autenticitet. I denne film er bl.a. den radikale brug affilmiske virkemidler med til at skabe autenticitet. Artiklen medtonker endvidere, at 'de såkaldte naturlige historier' ligeledes er strategier, der fremmaner folelsen af virkelighed både i Idioterne og andre nyere danske film.
\end{abstract}

Det seneste årti har vi set en lang række danske film og tv-serier, som i vid udstrækning har påkaldt sig oplevelsen af autenticitet. Det er ikke alene dogme-filmene, men også mange andre nye danske film, der 'leger' med virkeligheds-følelsen. Denne artikel vil fokusere på hvilke strategier, der medvirker til at iværksætte oplevelsen af autenticitet. For der er netop tale om strategier og iscenesættelser af noget, der virker ægte - uden naturligvis at være det. Forskellige improvisationsteknikker og eksperimenterende anvendelse af æstetiske virkemidler synes at være to blandt mange strategier. Samtidig kan de såkaldte 'naturlige historier', der indgår som undervisning på Den Danske Filmskole og ligeledes kan lokaliseres i en række af de nye danske film, også anskues som autenticitetsstrategier. ${ }^{1}$ Men hvad er egentlig en naturlig historie? Og hvordan influerer den på tilskuerens perception?

I artiklen vil jeg endvidere præsentere begreberne 'immediacy' og 'hypermediacy' fra bogen Remediation - Understanding New Media (2000/1999), der er skrevet af de amerikanske medieforskere Jay David Bolter og Richard Grusin. Ud fra disse vil jeg anskueliggøre, om autenticitetsstrategier som ovenstående bringer mere immediacy eller hypermediacy til de danske film. Eller om man kan argumentere for, at tilskueren opnår oplevelsen af immediacy netop via filmenes brug af hypermediacy, mens alt andet ville 'tale ned til' den moderne tilskuer. Som eksempler, der kan give diskussionen empirisk belæg, anvender jeg hovedsageligt Lars von Triers seneste to trilogier, dvs. »Guldhjertetrilogien" med Breaking the Waves (1996), Idioterne (1999) og Dancer in the Dark (2000) samt »Amerikatrilogien«, som (foreløbig) består af Dogville (2001) og Manderlay (2005). ${ }^{2}$ Triers film er valgt, fordi de rummer interessante dobbeltspil. På én gang skaber de nærvær og distance til tilskuerne. De er emotionelle og intellektuelle samtidig - skaber affekt via effekt. De anvender strategier til at skabe autenticitet. Hvordan dette indvirker på receptionen, vil jeg anskueliggøre i artiklen. ${ }^{3}$

\section{Autenticitet skabt via strategi}

Ordet autenticitetsstrategi er ved nærmere eftertanke en paradoksal størrelse. For hver især repræsenterer ordene: 'autenticitet' og 'strategi' to vidt forskellige bestræbelser. Når jeg spørger mine studerende, hvad de forbinder autenticitet med, så er svaret gerne: »noget virkeligt, noget ægte«. Når jeg tilsvarende spørger, hvad de forbinder strategi med? Så lyder svaret: »noget med en plan«. Følger man dét spor, så må en filminstruktør, der anven- 
der autenticitetsstrategier, altså lægge en plan for, hvordan man kan få noget 'virkeligt' frem, eller hvordan man får fiktionen til at virke ægte for tilskueren. Det paradoksale er naturligvis, at det virkelige gerne er forbundet med tilfældigheder og spontanitet snarere end med langtidsplanlægning; $\mathrm{og}$ fakta i stedet for fiktion.

Litteraturforskeren Søren Schou anvender i en artikel i antologien Gensyn med realismen (1996) et andet illustrativt begreb, nemlig 'virkelighedssuggererende effekter'. Appliceret på film kan virkelighedssuggererende effekter f.eks. være anvendelsen af et reportageagtigt formsprog (akontinuerlig klipning, håndholdt kamera, deframing, ufokuserede billeder, diegetisk lyd og musik mangelfuld belysning mv.). Brugen af forskellige improvisationsmetoder kan også betragtes som et greb, hvormed man gerne opnår at tilføre sine karakterer autenticitet. Når f.eks. håndholdt kamera og et 'løst' manuskript anvendes, giver det skuespillerne nogle anderledes og mere fleksible arbejdsforhold, under hvilke de kan agere mere frit end ved traditionelle optagelser og derved medvirke til at give karaktererne autenticitet. Lars von Trier har selv ageret kameramand i en række af sine seneste film, og ifølge den svenske skuespiller, Stellan Skarsgård, var dette netop med til at ændre arbejdsbetingelserne for skuespillerne i en positiv retning. Han giver i dvd-materialet til Dogville udtryk for, at stregerne på gulvet (som giver illusionen af huse mv.) og Trier bag kameraet gjorde arbejdet med karaktererne lystfyldt og let. Helt konkret kalder han det ikke for at arbejde, men bruger udtrykket, at »Leka med Lasse«. ${ }^{4}$ Han påpeger således, at brugen af innovative regler i filmskabelse medvirker til at skabe nye udfoldelsesmuligheder for skuespillerne, hvilket kan gøre arbejdet med karakteren lystfyldt og derigennem tilføje karaktererne ægthed.

Autenticitetsstrategier eller virkelighedssuggererende effekter som ovenstående kan medvirke til at give karaktererne autenticitet og potentielt tilbyde tilskuerne en oplevelse, som vi med henvisning til Bolter og Grusin kan kalde for oplevelsen af 'immediacy' eller 'the real'. Bolter og Grusin introducerer begreberne 'hypermediacy' and 'immediacy' for at uddybe, hvordan den såkaldte dobbelte logik virker, og det er givtige begreber at medtænke i forhold til f.eks. Triers film i bestræbelsen på at forstå dobbeltspillene. Derfor vender jeg tilbage til den dobbelte logik nedenfor. Hypermediacy gør seeren opmærksom på mediet og står dermed i modsætning til immediacy, der giver tilskueren/ brugeren en slags nærværs oplevelse, uden at mediet forstyrrer denne. Immediacy virker således ved at drage seeren ind i værket, som om vedkommende nærmest selv var til stede. Man kan tilføje, at immediacy - ligesom realisme - har at gøre med at skabe en særlig form for troværdighed eller autenticitet. Autenticitetsstrategierne må anses for at være retoriske greb, hvormed man får tilskueren til at leve sig ind i fortællingen og opleve momenter af immediacy.

Mange forskere - foruden Schou - har undersøgt og skrevet om den nye realisme-bølge på tværs af kunsten. Jf. f.eks. Om som om - realisme $i$ teori og nyere kunst (2002) eller Virkelighedshunger - nyrealismen $i$ visuel optik (2002). Skribenter i disse antologier synes enige om, at den nutidige (filmiske) realisme i højere grad er et spørgsmål om formsprog, om hvilke konventioner vi som tilskuere godtager som former, der berører os og virker autentiske, end det er et spørgsmål om at repræsentere den empiriske virkelighed i et 1:1-forhold. ${ }^{5}$

\section{Effekten af naturlige historier}

Endnu en autenticitetsstrategi eller en måde, hvorpå man kan skabe en virkelighedssuggererende effekter på film kan være at anvende de førnævnte 'naturlige historier', hvilket ligeledes er en strategi, som ofte kan lokaliseres i Triers film. En naturlig historie tager udgangspunkt i situationer, som virker genkendelige for tilskuerne. Når denne genkendelighed er etableret, vil der - rent dramaturgisk - være skabt grundlag for, at tilskueren kan overraskes via et brud med normerne. Autenticiteten beror således på, at tilskuerne kender de normer eller spilleregler, som er forbundet med den valgte naturlige historie. Når spillereglerne overholdes, tilbyder det tilskueren en oplevelse af noget genkendeligt, og samtidig rummer det også muligheden for, at filmskaberne kan bryde med spillereglerne og derved overraske publikum. Herved anvendes en vekselvirkning mellem dét, som Mogens Rukov kalder for 'normalitetens plot' og 'det skandaløses plot'. ${ }^{6}$ Normalitetens plot er den naturlige historie, mens skandalen udgør bruddet på normaliteten. I Vinterbergs Festen (1998) er normalitetens plot festens naturlige historie, fra gæsterne ankommer, til de tager af sted næste morgen. Skandalen er Christians (Ulrich Thomsens) taler, der afslører faderens incestuøse forhold 
til sine børn. Også den indledende restaurant-scene fra Triers Idioterne er opbygget efter at følge og bryde med konventioner, som forbindes med at gå ud og spise på restaurant. Ligesom vi efterfølgende ser vekselvirkningen mellem normalitet og skandale udspille sig i både svømmehal, på fabriks- og familiebesøg. I disse og andre situationer fra filmen bryder idiotspasseriet konstant med normerne for normal adfærd.

Rukov indkredser selv den naturlige historie på følgende vis:

[..] Det originale er bare en lille forandring inden for det dybt kendte. Og hvad er det dybt kendte? Det eneste som er dybt kendt for os mennesker er en serie af historier, ikke arketypiske historier, snarere er det historier, som vi er indblandet $\mathrm{i}$ hver eneste dag. Eller som vi kender mekanikken i fuldstændigt. Forudsætningen for, at man kan lave en overraskelse eller noget interessevækkende, er at grundlaget er noget vi kender mekanikken i. Det er sådanne historier som interesserer mig. Naturlige historier er f.eks. at gå på toilettet. Det er en naturlig historie. At tage en elevator er en naturlig historie. At gå ind i en bil (Rukov \& Christensen, 2002, s. 126)

I den indledende artikel i nærværende nummer af Mediekultur, »Remedierad vardag«, indkredser professor Orvar Löfgren et beslægtet fænomen, idet han skriver:

Vissa ting och vissa människoliv markeras som »mer verdagsliga« än andra. Vi möter det ofta när det är dags för lite socialrealism i film eller TV och man ska kontrastera olika klassvärder, ofta i form av utvalda etnografiska eksempel på vardagens mikrofysik. Det finns något förutsägbart i sätten att välje ut sådana vardagligheter, »natural stories« som så ska ges stark symbolisk kraft - en kulturell blinkning til publiken. Det kan vara sättet att tända en cigarett, läsa en tidning, bre en smörgås eller koreografin i en bilresa.

Dét, som Löfgren her kalder 'natural stories', minder om begrebet den naturlige historie. Dog har disse ikke altid en symbolsk effekt, men er først og fremmest med til at gøre fiktionen genkendelig og autentisk for publikum. Naturlige historier er des- uden ikke nødvendigvis en afspejling af hverdagens virkelige historier og dermed $\mathrm{i}$ bund og grund kedelige og uden de store begivenheder. Målet er $i k k e$ at skildre hverdagen, som den ville tage sig ud, hvis man f.eks. undersøgte den empirisk. Der er altså igen tale om en strategi, hvormed man opnår at give tilskueren oplevelsen af autenticitet $\mathrm{og}$ ikke en skildring af virkeligheden i et 1:1-forhold. Ideen er at arrangere denne vekselvirkning mellem naturlige historier og det skandaløse, således at tilskueren indlever sig i filmen ved at genkende og overraskes af situationerne på lærredet. Naturlige historier kan derved være med til at skabe grundlag for tilskuerens oplevelse af immediacy. Genkendelige situationer skal endvidere arrangeres, så de kommer til at udtrykke eksistentielle problemstillinger, for det er naturligvis oftest disse - og ikke hverdagen som sådan - der optager såvel filmkunstnere som tilskuere.

\section{Naturlige historier fra Filmskolen}

I en undersøgelse, jeg har lavet på Den Danske Filmskole, medvirkede bl.a. instruktøren Martin Strange-Hansen. ${ }^{7}$ Adspurgt hvad han anså for at være den største gevinst ved Filmskolens uddannelser, svarede han:

Jamen det var jo nok dét, vi lærte det første halve år. Det var de tre ord: 'den naturlige historie', som vi blev introduceret til, som går ud på, at alt hvad man gør, har en naturlig historie. Og man kan skabe gode scener, man kan skabe livagtige scener, hvis man bringer sin konflikt ind i noget - for eksempel en naturlig historie (Philipsen 2005, s. 202)

Strange-Hansen nævnte således Filmskolens introduktion til den naturlige historie, som det første han kom i tanke om, da han blev bedt om at udpege et udbytte ved uddannelsen som filminstruktør. Han fremhævede bl.a. den berigende effekt, som brugen af den naturlige historie kan have f.eks. i forhold til oplevelsen af en karakter. Hvis man som filmskaber ikke tænker i klichéer, men tør placere sine karakterer overraskende steder, og følge de naturlige normer, der følger med disse locations, så kan man ifølge Strange-Hansen opnå at give scenerne genkendelighed og autenticitet. ${ }^{8}$

I Strange-Hansens egne film myldrer det med 
naturlige historier, der samtidig er med til at diskutere eksistentielle problemstillinger. På hverdagsseminaret ved Copenhagen Buisness School d. 3. november 2005 - afholdt af Sammenslutningen af Medieforskere I Danmark, SMID - viste instruktøren selv en række eksempler, hvor et af dem var en scene fra novellefilmen Når lysterne tandes (2001). Her smører den kvindelige hovedperson Anita (Anette Støvelbæk) madpakke til sin mand, den mandlige hovedperson, Klaus (Jesper Asholt). Da tilskueren ved, at Klaus lyver for sin kone og slet ikke skal på forretningsrejse, men blot ud på eventyr, giver det ikke blot genkendelighed, men også substans til scenen, at Anita gør sig meget umage med madpakken og derved erklærer sin kærlighed til manden, mens skandalen lurer lige om hjørnet i forhold til deres ægteskab. Man kunne nemt nævne eksempler fra mange andre danske film, hvor instruktører som f.eks. Per Fly, Ole Christian Madsen, Susanne Bier og Thomas Vinterberg (alle uddannet fra Den Danske Filmskole i øvrigt) er flittige brugere af naturlige historier. Hvad jeg ønsker at fremhæve her er imidlertid ikke kvantiteten af naturlige historier, men snarere hvorledes disse anvendes som én blandt flere autenticitetsstrategier i nye danske film.

Der har selvklart altid været gjort brug af naturlige historier i kunsten. Det er ikke noget, som Mogens Rukov - i kraft af sin position som manuskriptforfatteruddannelsens leder på Den Danske Filmskole - har opfundet. Men han har i høj grad med sin undervisning på Filmskolen og sin indflydelse på dansk film generelt - som manuskriptkonsulent mv. - skærpet filmskabernes bevidsthed om brugen af de naturlige historier. Deri ligger også en befrielse for eleverne på Filmskolen eller filmskaberne i film- og tv-branchen. Præstationsangsten mindskes, når de forholder sig til f.eks. at skabe en bestemt slags scene, $\mathrm{i}$ stedet for at de fritstilles til at lave en scene om hvad som helst. Heri ses også en klar parallel mellem de naturlige historiers spilleregler og opfindelsen af Dogme-reglerne.

\section{Den komplekse dobbelte logik i Triers trilogier}

Lad mig - med Triers film som eksempler - nærmere anskueliggøre, hvordan autenticitetsstrategier kan være med til at give tilskueren en oplevelse af immediacy, hvilket er den ene dimension i Bolter og Grusins såkaldte 'dobbelte logik' ('The twin logics'). ${ }^{9}$ I Remediation - Understanding New Media, beskrives den dobbelte logik som udtryk for det paradoks, at vi i vores kultur skaber stadig mere avancerede højteknologiske medier i bestræbelsen på at opnå umedierede oplevelser. Som de anfører: »Our culture wants both to multiply its media and to erase all traces of mediation: ideally, it wants to erase its media in the very act of multiplying them«(Bolter \& Grusin, 2000, s. 5). Skal man følge Bolter og Grusin, så er det altså 'the desire to get beyond mediation', som mediebrugere eftertragter, oplevelsen af at sanse noget æogte, 'the real', uden samtidig at sanse mediet. Virtual reality er et godt eksempel på avanceret apparatur, der kan være med til at opfylde dette ønske. I Remediation fremhæves 'the wire' fra filmen Strange Days, idet "[..] the wire embodies the desire to get beyond meditation" (Bolter \& Grusin, 2000, s. 4). 'The wire' er et apparat, der giver adgang til en form for virtuel reality, hvor sanseindtryk fra én hjerne kan optages og overføres til en anden, uden at selve apparatet bemærkes. Som Bolter og Grusin videre anfører: »[..] the wire is designed to efface itself, to disappear from the user's consciousness" (Bolter \& Grusin, 2000, s. 4).

Mere og mere kompliceret og avanceret medieteknologi giver ifølge Remediation bedre og bedre betingelser for at opfylde seerens begær (desire) efter immediacy. Dette begær må derved også være dét, eller i hvert fald en del af dét, som eksempelvis filmskabere og computerproducenter eftertragter og bruger store summer på at kreere - eller hvad? Ifølge Bolter og Grusin bliver der netop brugt mange penge på at opfylde seernes higen efter immediacy. Som de skriver: »Filmmakers routinely spend tens of millions of dollars to film on location or to recreate period costumes and places in order to make their viewers feel as they were 'really' there" (Bolter \& Grusin, 2000, s. 5). Dette er naturligvis rigtigt, hvis man eksempelvis tænker på tv-serien Kroniken (DR, 2005). Her blev netop anvendt store summer på at skabe de rette historiske kulisser og derved et tidssvarende miljø, hvilket givetvis var medvirkende til at skabe indlevelse hos de mange seere. Jeg vil dog betvivle, at det nødvendigvis behøver være summen af penge anvendt til f.eks. kulisser eller computeranimation, der sikrer tilskueren oplevelsen af immediacy. De danske dogme-film er glimrende eksempler på, at den form for indlevelse også kan kreeres for sølle fem millioner kroner. 
Bolter og Grusin fremsætter desuden det statement, at for at opnå immediacy 'the medium has to be transparent'; altså de audiovisuelle virkemidler som f.eks. klipning, kameraføring, lys, lyd mv. må anvendes på måder, der ikke påkalder sig opmærksomhed. Men er dette nødvendigvis en forudsætning for at opleve den beskrevne immediacy? Spørgsmålet er, hvad vi som seere higer efter, og hvordan behovet opfyldes af medierne? Er ophævelsen eller forglemmelsen i forhold til selve mediet vitterlig dét, vi som seere efterstræber, og hvis vi gør, er forudsætningen så, at mediet anvendes på en transparent måde? Bringer man spørgsmål som disse med sig ind i nogle analytiske nedslag $\mathrm{i}$ Triers to seneste trilogier, så får man umiddelbart et mere nuanceret billede af den dobbelte logik, end det Bolter og Grusin tegner. Jeg vil nedenfor argumentere for, at Trier med sine værker formår at skabe scener, der rummer stor intensitet og derved drager tilskueren ind i fiktionen, uden at der lægges skjul på, at det netop er fiktion. Man kunne kalde disse intense scener for immediacy og anskueliggøre, hvordan de iscenesættes via forskellige former for autenticitetsstrategier, hvor strategierne langt fra er usynlige (hypermediacy).

\section{Remediering og tilskuertyper}

Tidligere nævnte jeg et reportageagtigt filmsprog som en autenticitetsstrategi. Her må filmsproget siges at låne virkemidler fra tv-reportagen. ${ }^{10}$ Når man eksempelvis i brugen af audiovisuelle virkemidler i en film låner fra et andet medie, så kalder Bolter og Grusin dette for 'remediation'. Film kan låne virkemidler fra computer, tv, bøger, malerier, fotografier mv. - og omvendt. Igennem mediehistorien har vi observeret en konstant remediering mellem forskellige medier. Denne konvergens smitter af på medierne både frem og tilbage i historien. Bolter og Grusin anfører: »What is new about the new comes from the particular ways in which they refashion older media and the ways in which older media refashion themselves to answer the challenge of new media« (Bolter \& Grusin, 2000, s. 15). Som jeg vil uddybe, er denne remediering ifølge de to medieforskere at betragte som led i en stræben efter at give mediebrugerne den optimale oplevelse af 'the real'. Trier anvender flittigt remediering på tværs af sine værker. Man kan betragte dette som endnu en autenticitetsstrategi.

I Dogville og Manderlay ses eksempelvis remedi- ering på tværs af medier som bog, teater og film. Professor Torben Grodal gør i en artikel, »Frossen glød: Modsætninger og ambivalenser i Lars von Triers filmkunst«, opmærksom på, at Dogville og Manderlay kan ses som: »blandinger af minimalistisk avantgarde-teater i 60'er-stil og det 19. århundredes naturalistiske roman « (Grodal, 2005, s. 43). Herved påpeger han - uden dog at henvise til Bolter og Grusin - den remediering, som findes i filmene. Perspektivet udvides yderligere, når han skriver, at Triers film er lavet: »[..] med inspiration fra andre film, romaner, malerier eller fotografier og ikke mindst tv« (Grodal, 2005, s. 47).

I Breaking the Waves opereres i kapitelinddelingerne med en remediering fra henholdsvis bogen, musikken og maleriet. Hver gang et nyt kapitel introduceres i filmen via maleri, musik og tekst, så gøres disse medier - sammen med filmmediet - særdeles synlige, altså er der tale om hypermediacy. Som tilskuer bliver man opmærksom på, at man sidder i en biografsal og overværer et stykke fiktion. Man får øje på effekterne. Denne hypermediacy skaber derved en form for distance og metarefleksion. Når kapitelinddelingerne afløses af dét, vi kunne kalde for selve kapitlerne, ophæves distancen imidlertid, og i stedet skabes grundlag for en oplevelse af nærhed, affekt og indlevelse - immediacy. Man skulle mene, at det metarefleksive lag videreføres i kapitlerne, idet tydelig brug af håndholdt kamera, akontinuerlig klipning og flere direkte cameralooks ind i kameraet konstant gør opmærksom på mediet. Men skal man tro f.eks. de mange læserbreve, der fulgte i kølvandet på filmen, så er der i høj grad tale om, at Breaking the Waves fik tilskuerne til at leve sig ind i fiktionen, som om den var autentisk.

\section{Intellektuel og emotionel}

Knud Michelsen skriver i artiklen, »Etikken som rekvisit: Om Lars von Triers Dogville og Manderlay« (2005), at Triers film på én gang er hyperintellektuelle og hyperemotionelle:

Der er voldsomme følelser i spil, ekstreme menneskelige situationer, men inden for et strengt regelstyret og intellektualiseret koncept. I modsætning til så mange andre af nutidens film indbyder de hermed ikke til fortrolig identifikation, men til udforskning af et særegent kunstnerisk univers. Det betyder ikke, at de historier, de 
fortæller, ikke umiddelbart appellerer til medleven og følelsesmæssigt engagement. Tværtimod rummer de en suggestiv kraft, som lader de færreste uberørt [..] (Michelsen, 2005, s. 51)

Michelsen fremhæver, at især Breaking the Waves og Dancer in the Dark indbyder til dette engagement, mens Dogville og Manderlay har en fremtrædende intellektuel side, der fylder mere end den emotionelle. Jeg vil medgive Michelsen disse betragtninger, ligesom jeg kan tilslutte mig hans analyse af, at »Amerika-trilogien« i endnu højere grad end »Guldhjerte-trilogien« rejser moralske spørgsmål. Men spørgsmålet om, hvorvidt man som tilskuer identificerer sig med hovedpersonerne eller ej, må anskues endnu mere nuanceret, end Michelsen gør. Jeg vil argumentere for, at det afhænger af øjnene, der ser, dvs. forskellige typer af tilskuere.

Den italienske litteraturteoretiker og forfatter, Umberto Eco, opererer i artiklen »Fornyelse i det serielle« (Eco, 1990, s. 125) med to typer af tilskuere: 'den naive' og 'den kritiske læser'. Han betragter i artiklen intertekstualitet som en dialektik mellem det skematiske og det fornyende. Denne dialektik skal opfattes af læseren, og det er væsentligt, at han/hun forstår måden, hvorpå budskabet formidles. Idet måden, der citeres på, ofte er ligeså (eller mere) vigtig, end indholdet af det citerede. Man kan anføre, at intertekstualiteten skaber to lag i det fortalte. Et lag der 'kun' vedrører selve historien, og et lag af citater der giver noget mere til den erfarne, kritiske og kompetente læser, uden at ødelægge historien for den, der ikke kender citaterne. Ud fra dette ses den kritiske læser, som én der opfatter citaterne og nyder dem for det, de oftest er: en leg med medier og tilskuere. Den naive læser, derimod, lægger ikke mærke til intertekstualitet og hermed det/de ekstra lag. ${ }^{11}$ Ligesom Eco således skelner mellem den naive og den kritiske læser og konstaterer, at de fleste tv-serier primært henvender sig til den naive læser, der f.eks. ikke aflæser intertekstualitet og forholder sig kritisk til fakta og fiktion, så kan vi tilføje, at det nok primært er den kritiske læser, der eksempelvis oplever immediacy som folge af hypermediacy i Triers værker.

Den naive læser vil formodentlig have lettere ved at identificere sig fortroligt med f.eks. hovedpersonen, end den kritiske læser vil; denne oplever måske nærmere empati. Dermed mener jeg, at Knud Michelsens pointe om, at tilskueren enga- gerer sig uden at identificere sig, bør udvides med betragtninger om forskellige typer af strategier fra Triers hånd og forskellige tilskuerinstanser. Når Michelsen anfører, at især Breaking the Waves og Dancer in the Dark skaber engagement, så må dette ses i lyset af, at Triers trilogier eksemplarisk følger de gamle retoriske strategier: logos, pathos og ethos. Jeg har tidligere beskrevet, hvorledes Trier i »Europa-trilogien« (Element of Crime/Forbrydelsens element, Epidemic og Europa) anvender logos (fornuft) som retorisk strategi, hvorved han med filmenes mange intellektuelle og intertekstuelle puslespil mest henvender sig til den kritiske læser. Mens »Guldhjertetrilogien« benytter pathos (lidelse) som strategi, hvorved også den naive læser bringes i følelsesmæssig dialog og måske herigennem oplever identifikation. ${ }^{12}$ Endelig antog jeg i artiklen, at ethos (etik) formodentlig måtte være den næste strategi, som Trier ville afrunde trilogiernes trilogi med. Og de mange etiske dilemmaer, som "Amerika-trilogien « rejser, taget i betragtning, så ser min analyse af Triers retoriske strategier ud til at holde stik. Jeg mener, som Michelsen, at: »De spørgsmål, de tager op [Dogville, Manderlay], brager lige ind i nutidens diskussioner om menneskerettigheder, menneskesyn og grundlæggende værdier (Michelsen, 2005, s. 54). Dermed opfordrer de til en etisk stillingstagen fra tilskuerens side, hvilket igen er med til at sikre indlevelse og empati, men ikke nødvendigvis identifikation. Michelsen gør i artiklen opmærksom på, at fortælleren i Manderlay rejser spørgsmålet om, hvorvidt Graces ønskede frigivelse af slaverne vil indebære en berigelse for dem (Michelsen, 2005, s. 62). Svaret synes at være nej, idet slaverne uden den såkaldte 'Mams Law' får det værre end ved håndhævelsen af denne. Svaret er imidlertid ikke entydigt, men op til tilskuernes vurdering. Grace udsættes af slaven Wilhelm for en prøve, hvor han vil (be)vise, at Grace i virkeligheden gerne vil indsættes som den nye Mam (modsat hendes oprindelige visioner). Og idet hun ender med at udsige og selv eksekvere en dødsdom over Wilma, den gamle kone, der stjæler den syge piges mad, udgør hun en slags Mam. Grace bliver således samtidig endnu en idealist, der går til grunde (som Fisher i The Element of Crime, Bess i Breaking the Waves m.fl.).

Michelsen har endvidere en vigtig analytisk pointe, idet han observerer, at: 
Manderlay kan siges at repræsentere en direkte omvending i forhold til Dogville, en omvending, der yderligere forstærkes af de formelle overensstemmelser (og af ombytningen af farvelægningen på 'scenegulvet'). I Dogville kommer Grace som flygtning til Dogville og forlader byen som den retfærdige dommer. I Manderlay kommer hun som den retfærdige dommer og forlader stedet som flygtning. I Dogville bliver hun slave, mens hun i Manderlay befrier slaverne (2005, s. 63)

Begreberne fra Remediation anvendes ikke af Michelsen i artiklen. Men de kunne yderligere være med til at udbygge og underbygge hans gode analytiske iagttagelser, idet hans betragtninger om det hyperemotionelle præg og det intellektuelle præg yderligere kan beskrives med ordene immediacy og hypermediacy. Det er påfaldende, som han også bemærker, at både Dogville og Manderlay er opbygget omkring et enkelt teateragtigt rum med streger på gulvet og omvendte farvekombinationer (hvide streger på sort baggrund og sorte streger på hvid baggrund). Disse streger gør det ud for huse, hunde, træer mv. Man kan roligt sige, at de samtidig udgør en stærk form for hypermediacy, der endvidere forstærkes af den alvidende fortælleinstans (en voice-over), som bl.a. stiller tilskueren nogle af filmenes mange etiske spørgsmål. Også det håndbårne kamera, kapitelinddelingerne mv. bringer - som ved »Guldhjerte-trilogien« - hypermediacy ind i værket. Der er med andre ord masser af synlighed omkring mediebrugen, som ifølge Bolter og Grusin skulle forhindre tilskueren oplevelse af immediacy. Jeg har overværet flere forestillinger (både hvad angår »Guldhjerte-« og »Amerika-trilogi«), hvor publikum højlydt gav udtryk for lysten til at forlade biografsalen efter de første 10-15 min. Herefter blev der stille, og ingen forlod filmene. Jeg har også ved flere lejligheder (i min undervisning og ved foredrag) diskuteret »Amerika-trilogien« med tilskuere, som - ved filmenes begyndelse - havde svært ved at acceptere eksempelvis stregerne på gulvet, hvorpå de hengav sig til dramaet og rent 'glemte' karakteren af hypermediacy. Samme ytringer kan man opleve i forbindelse med Dancer in the Dark, hvor det første musicalnummer voldte en del tilskuere kvaler, mens resten af filmen gav rig anledning til indlevelse.

Man kan ud fra ovenstående argumentere for, at hvis det konstruerede drama er overbevisende nok i sig selv, så forhindrer en synlig konstruk- tion ikke nødvendigvis oplevelsen af immediacy. Måske er det tværtimod sådan, at den moderne, kritiske tilskuer/læser har lettere ved at 'overgive' sig til en synlig iscenesættelse af en fortælling iscenesat som om den var autentisk end den naive og transparente konstruktion af samme. Streger på gulvet er sandsynligvis med til at give tilskuernes egen fantasi rige muligheder for udfoldelse, hvilket måske tiltaler publikum, som det ofte sker, når man oplever et maleri eller læser en bog.

\section{Idioternes pinagtige autenticitet}

Også i Idioterne er tilskuerne en slags meddigtere, idet denne radikale film - om et spasserkollektivs ikke særlig målrettede gøren og laden - fordrer en koncentreret perception og indlevelse. Noget der er med til at sikre, at publikum forholder sig aktivt til Idioterne, er dens mange grænsesøgende scener. Filmforskeren Ove Christensen har skrevet artiklen »Spasserfilm - nærhed og distance i Idioterne« (2004). I den kredser Christensen netop om Idioternes pinagtige væsen. Han anfører bl.a., at en del af filmens radikalitet ligger $\mathrm{i} »[.$.$] den følelse af$ pinlighed, man oplever, når man ser filmen « (Christensen, 2004, s. 52). Især den sidste scene i filmen føles grænseoverskridende pinlig for publikum. Jeg har flere gange vist den for studerende, som typisk reagerer ved enten at vende hovedet væk, grine eller komme med mishagsytringer. Flere har også givet udtryk for, at scenen i bogstaveligste og derved fysisk forstand giver dem kvalme. Herved 'afslører' de studerende, at de lever sig ind i filmen med stor empati - uden nødvendigvis at identificere sig med hovedpersonen, Karen (Bodil Jørgensen).

Slutscenen er særdeles central i filmen, idet den klart kommunikerer, at Karen formår at føre 'spasseriet' ud i livet og derved give hele Stoffers (Jens Albinus) idiotprojekt, som ellers er under opløsning, en værdi. Hun bruger spasserrollen til at udleve sin indre idiot og markere en holdning over for sin uforstående familie. Det viser sig jo i denne sidste scene, at Karen bærer rundt på et ubearbejdet traume, idet hun og hendes mand har mistet et spædbarn. Da hun beklager over for sin mand, at hun ikke deltog i begravelsen, konstaterer han spydigt, at det blot med al tydelighed viser, hvor lidt ked af det hun er. Karens reaktion ovenpå denne groteske misforståelse er at spasse ved langsomt og demonstrativt at spytte kagen ud af munden igen. 
Hele familien stivner, og ægtemandens respons er at give hende en lussing.

Scenen viser således med al tydelighed, at der huserer kommunikationsbrist i familien. Konsekvensen er, at den sorg som Karen bærer rundt på, må ytre sig på anden vis end via ord, nemlig $\mathrm{i}$ hendes outrerede kropssprog og hans lussing. Det kan synes upassende, at hun først forlader familien, udebliver fra begravelsen og derefter tager hjem til familien igen og spasser. Men, hvad scenen illustrerer, er snarere, hvor upassende og ja, idiotisk hendes familie reagerer på sorg. Det fremstilles således, hvordan Karen må ud med sine egentlige følelser og nægter at spille rollen som den afbalancerede mor, der fint kan sidde til søndagskaffe i familiens skød uden at bryde med normerne. I dette genkender vi klart brugen af normalitetens plot, altså den naturlige historie og bruddet med denne: det skandaløses plot. Karens idiotrolle adskiller sig fra de andre kollektivisters dels ved at være frivillig og ikke påtvunget, hvilket ifølge Ove Christensen gør »hendes 'spasning' mere ægte«. (Christensen, 2004, s. 61). Han kalder det også for hendes 'egentlige jeg', der kommer frem (Christensen, 2004, s. 62).

Når man som tilskuer på denne scene reagerer med afsky (som f.eks. mine studerende), så hænger det sandsynligvis sammen med voyeurisme. Vi vil gerne overvære noget forbudt og hemmeligt, men samtidig er dette næsten for privat, og det bliver ikke nemt at finde en passende grimasse, når man ser scenen sammen med andre. Christensen anfører om denne scene, at: »De følelser, der er på spil, er så intense, at tilskueren føler sig intimt involveret«(Christensen, 2004, s. 56). Generelt om filmen ytrer han endvidere, at: »Følelsen af pinlighed er udtryk for filmens vellykkethed i forbindelse med en direkte kommunikation af følelser« (Christensen, 2004, s. 53). Samtidig undrer han sig over, at man som tilskuer oplever mange af scenerne $\mathrm{i}$ filmen så pinlige, når man samtidig er velvidende, at det er det rene opspind, man sidder og krummer tæer over. Jeg vil gerne argumentere for, at det bl.a. er filmsprogets synlige og på alle måder autonome karakter, der faktisk medvirker til at skabe indlevelsen i Idioterne. Filmsproget slægter tv-sproget på, og der er desuden gjort brug af improvisation, altså figurerer der i denne film flere af de autenticitetsstrategier, som er præsenteret her i artiklen.

Vi har i Idioterne at gøre med en slutscene, der - med rette - făr en filmforsker som Ove Christensen (og andre med ham) til at anvende følelsesla- dede ord som: 'ægte', 'indre idiot', 'egentlige jeg', 'pinlighed', 'direkte kommunikation af følelser' mv. Vi har endvidere at gøre med en film, der får både filmforskere og tilskuerne til at reagere voldsomt. Det ligger derfor lige for at konkludere, at Idioterne både opfylder tilskuerens begær efter immediacy og Dogmemanifestets visioner. Læser man Kyskhedsløftet, så står der f.eks.:

At lade personernes indre liv retfærdiggøre handlingen er for kompliceret og ikke »fint «. Som aldrig før hyldes den yderlige handling og den yderlige film. Resultatet er goldt. Det er en illusion af patos og en illusion af kærlighed. For Dogme 95 er film ikke en illusion! (Vinterberg, 1998, s. 5)

Her kritiserer dogme-brødrene altså andre filmmagere for at hylde den ydre handling på bekostning af den indre. Dét, de selv vil med deres film, er at skabe et alternativ, hvor filmene netop giver oplevelsen af patos (lidelse) og kærlighed. Senere i Kyskhedsløftet står der yderligere: »Mit ypperste mål er at aftvinge mine personer og scenarier sandheden « (Vinterberg, 1998, s. 8). Ud fra ovenstående analyse af den sidste scene fra Idioterne, mener jeg, man kan konkludere, at der i hvert fald i denne del af filmen er masser af patos, kærlighed og 'sandhed'. Det ligger ligeledes lige for at konkludere, at Idioterne (i visse scener) emmer af en immediacy, der kommer i stand via forskellige autenticitetsstrategier (en improvisationsteknik, en instruktør der selv har ført kameraet, et eksperimenterende filmsprog, der kan betragtes som en remediering af tv-sprog mv.). Men har man anført dette, må man straks tilføje, at det langt fra er en transparent immediacy. Tværtimod er virkemidlerne særdeles synlige hele vejen igennem - dvs. at filmen samtidig er et udtryk for hypermediacy.

\section{Sammenfattende om kompleksiteten}

Således kan vi samlet konkludere, at Idioterne - som de andre film i Triers seneste to trilogier - er udtryk for et langt mere komplekst forhold mellem immediacy og hypermediacy, end det kommer til udtryk hos Bolter og Grusin i Remediation. Man kunne fristes til at anføre, at det netop er filmenes hypermediacy, der udgør grundlaget for, at den moderne, kritiske tilskuer (grundigt oplyst om at 
dette er fiktion) tør hengive sig til indlevelsen i disse værker dermed opleve immedacy. Det må igen medtænkes, at der naturligvis findes forskellige typer af tilskuere, som vil reagere forskelligt på hypermediacy. 'Den naive tilskuer/læser' (jvf. Eco, 1990) vil muligvis ikke få øje på filmens hypermediacy. Mens 'den kritiske læser' sandsynligvis vil forholde sig til denne, uden at det nødvendigvis fratager oplevelsen af immediacy.

Hvor det givetvis er eksperimenterne med formsproget, der kunne forårsage, at nogle typer af tilskuere ville udvandre fra biografen under en Trier-film, så vil andre autenticitetsstrategier formodentlig være med til at trække tilskuerens overvejelser og oplevelser i en anden retning. Både improvisationsteknikker og anvendelsen af naturlige historier er i denne artikel blevet anskuet som strategier, der kan medvirke til at fremmane genkendelighed, indlevelse og dermed måske immediacy fra tilskuerens side. Får stregerne i Dogville og Manderlay eller den meget akontinuerlige klipning i Idioterne og Breaking the Waves eller musical-numrene i Dancer in the Dark nogle tilskuere til at søge mod udgangen, så kan oplevelsen af autenticitet forårsaget af improvisation og naturlige historier måske medvirke til at få dem bænket i biografsæderne igen. Som Knud Michelsen skriver om »Amerikatrilogien«, så vil »Dogville og Manderlay [..] ikke blot være gode historier, men insisterer på en virkelighedsrelation« (Michelsen, 2005, s. 68).

Vi kan også sammenfatte, at man som filmskaber ikke nødvendigvis behøver bruge 'tens of millions of dollars' på at skabe grundlag for en oplevelse af immediacy. Eksempelvis kostede de første fire dogme-film kun ca. fem millioner kroner stykket. Endelig er det også en væsentlig pointe, at hypermediacy - f.eks. i form af streger på gulvet og håndholdt kamera - medvirker til at kreere nye udfoldelsesmuligheder for skuespillerne, hvilket kan gøre arbejdet med karakteren lystfyldt og tilføje karaktererne ægthed. Samtidig skaber denne hypermediacy nye muligheder for tilskuernes indlevelse, idet de opfordres til at engagere sig og bruge deres fantasi særdeles livligt, når huse f.eks. er erstattet af streger på gulvet.

Jeg har nu anvendt begreber fra Remediation på dele af Triers seneste to trilogier og derved indkredset det komplekse forhold til den dobbelte logik, som her eksisterer. I perspektiverende øjemed kan nævnes film af andre instruktører end Trier, f.eks. Christoffer Boes Reconstruction (2003) eller Pernille Fischer Christensens En soap (2006). I Reconstruction peges allerede i titlen på filmens konstruktion, og tilskueren drages aktivt ind $\mathrm{i}$ at rekonstruere en kompleks kærlighedshistorie, som på alle måder - både hvad angår handling og formsproget der formidler denne - er usammenhængende. I klipning såvel som billedbeskæring og intertekstuelle referencer mv. udpensles derved filmens hypermediacy. Men på trods - eller måske på grund - af denne rummer filmen alligevel mulighed for at opleve immediacy. I En soap afbrydes handlingens flow løbende af stillbilleder og en voice-over, der i bedste soap-stil stiller spørgsmål som: »Hvad vil Charlotte gøre nu? «. Derved rummer filmen både hypermediacy og også en remediering af tv-mediet i film-mediet, idet soapen er en tv-genre (tænk f.eks. på Desperate Housewives eller Beverly Hills 90210). Disse 'afbrydelser' forhindrer dog ikke, at filmens historie og karaktertegning er så medrivende, at indlevelsesmulighederne, og dermed immediacy, i udstrakt grad er til stede. Man kan tilføje, at den udstrakte brug af naturlige historier med normalitetens plot og skandalens plot, både i Reconstruction og En Soap, ligeledes er med til at skabe mulighed for tilskuerens oplevelse af immediacy. ${ }^{13}$

Man kunne have mange andre medieværker for øje, hvor diskussionen ud fra Bolter og Grusins begreber kunne fortsættes. I analyserne af nye film og deres konvergens og autenticitetsstrategier - især i udtryksformerne - tilbyder Remediation gode rammer at debattere inden for. Men der er også begreber, som med fordel kan gentænkes, så de mere præcist indkredser det forhold, der er på spil mellem hypermediacy og immediacy f.eks. i Triers seneste trilogier samt en lang række andre nye, danske film. Lad dette være en opfordring til i filmanalytisk sammenhæng at tænke med og mod Remediation i bestræbelsen på at udforske og forstå nye film - og deres fremstilling af medier og virkelighed - bedre.

\section{Litteratur}

Bolter, J. D., \& Grusin, R. (2000/1999). Remediation - Understanding New Media. The MIT Press.

Christensen, O. (2004). "Spasserfilm - nærhed og distance i Idioterne«. In Nogne billeder - de danske dogmefilm. Christensen, O. (Ed.) Medusa.

Eco, U. (1990). »Fornyelse i det serielle«. In: Om spejle og andre forunderlige fenomener. Forum.

Eco, U. (1995). Fortolkning og overfortolkning, Collini, S. (Ed.) Systime. 
Grodal, T. (2005). »Frossen glød: Modsætninger og ambivalenser i Lars von Triers filmkunst«. In Jespersen, A., \& Jørholt, E. (Eds.). Som i et spejl: Om film og filmkunst-et festskrift til Peter Schepelern. Ries.

Jørgensen, H. (2002). »I virkeligheden er tingene ikke som I en musical - I Dancer in the Dark er tingene ikke som i en musical«. In Om som om - realisme i teori og nyere kunst, Iversen, S., Jørgensen, H. \& Nielsen, H.S. (Eds.) Akademisk Forlag.

Jørgensen, H. (2004).«Nye dansk don’t feel good-film: Et interview med Annette K. Olesen«. In 16:9 (april 2004) http://www. 16-9.dk/2004-04/pdf/16-9 april2004 side06 annetteolesen.pdf

Knudsen, B. T. \& Thomsen, B. M. (2002). Virkelighedshunger - nyrealismen $i$ visuel optik. Tidernes skifter.

Michelsen, K. (2005). »Etikken som rekvisit: Om Lars von Triers Dogville og Manderlay«. In A. Jespersen \& Jørholt, E. (Eds.) Som i et spejl: Om film og filmkunst - et festskrift til Peter Schepelern. Ries.

Philipsen, H. (2005). Dansk Films nye bolge - afset og aftryk fra Den Danske Filmskole (intern udgivelse ved Syddansk Universitet).

Rukov, M. \& Christensen, C. (2002). Festen og andre skandaler. Lindhardt og Ringhof.

Schepelern, P. (1997). Lars von Triers elementer: en filminstruktors arbejde. Munksgaard - Rosinante.

Schou, S. (1996). »Realisme og pretext« in Holmgaard, J. (Ed.) Gensyn med realismen. Medusa.

Vinterberg, T. (1998). Festen: Alle familier har en hemmelighed. Per Kofoed.

\section{Film:}

Boe, C. (2003). Reconstruction

Christensen, P. F. (2006). En soap

Strange-Hansen, M. (2001). Når lysterne tendes

Trier von, L. (1996) Breaking the Waves, (1999) Idioterne, (2000) Dancer in the Dark, (2001) Dogville, (2005), Manderlay

Heidi Phillipsen er adjunkt ved Center for Medievidenskab på Syddansk Universitet.

\section{Noter}

1 Brugen af naturlige historier ses - foruden i Dogmefilmene og Lars von Triers øvrige film - også i f.eks. Annette K. Olesens Små ulykker (2002), Per Flys trilogi, Benken (2000), Arven (2003) og Drabet (2006), Susanne Biers Brødre (2004) og Efter Brylluppet (2006), Christoffer Boes Reconstruction (2003) og Pernille Fischer Christensens En soap (2006). De to sidstnævnte værker medtænkes i artiklens perspektivering, sidste afsnit.

2 Det har hele tiden været Triers plan at slutte trilogien med filmen Washington. Men blandt andet grundet meget små tilskuertal til Manderlay, er det uvist, om trilogien nogensinde færdiggøres. Triers seneste film, komedien $D i$ rektoren for det hele (2007), er således ikke en del af denne.

3 Jeg har en artikel på engelsk under udgivelse i bogen Moving Media Studies - Remediation Revisited, som går mere i dybden med at diskutere Bolter og Grusins begreber.
Planlagt publiceret sommer 2007 under titlen »Remediation in Trier Trilogies«. I denne artikel arbejder jeg med begreber som 'præsentationens immediacy' og 'repræsentationens immediacy', hvilket udvider diskussionen om, hvorvidt man skal forstå Bolter og Grusins immediacy-begreb så forholdsvist naivt, som det fremlægges i Remediation, og som det anskues i nærværende artikel.

4 'Lasse' er Stellan Skarsgårds kælenavn for Lars von Trier.

5 Se i øvrigt Gunhild Aggers artikel om tv-serien Kronprinsessan i nærværende udgivelse. Her reflekterer Agger ligeledes over realisme-begrebet og -tendensen bl.a. ud fra litteraturteoretikeren Søren Schous indkredsning af begrebet.

6 Mogens Rukov er leder af manuskriptforfatteruddannelsen på Den Danske Filmskole, hvor han har arbejdet siden 1975 og udøvet stor indflydelse på udviklingen af de forskellige læringsmetoder. Læren om den naturlige historie indgår både på fællesfaget dramaturgi (som alle filmlinjer deltager i) og på manuskriptforfatteruddannelsen.

7 Jeg har skrevet ph.d.-afhandlingen Dansk films nye bølge: afset og aftryk fra Den Danske Filmskole (2005). Den er baseret på en kvalitativ undersøgelse af Filmskolens rolle i dansk films positive udvikling fra midten af 1990'erne $\mathrm{og}$ frem. Blandt mine respondenter var blandt andet tidligere elever fra årgang 2001, hvor instruktøren, Martin Strange-Hansen, var én af dem.

8 For uddybning af den naturlige histories rolle på Den Danske Filmskole: se min ph.d.-afhandling, kapitel syv.

9 Målet i denne artikel er - som nævnt indledningsvis - at diskutere autenticitetsstrategier i lyset af begreber fra Remediation. Jeg ønsker således ikke at give fyldestgørende analyser af Triers værker. Her kan jeg henvise til forskning af bl.a. Peter Schepelern (Københavns Universitet) og Lisbeth Overgaard Nielsen (Aarhus Universitet), ligesom bogen Som $i$ et spejl (2005) tilbyder interessante analyser af nogle af Triers værker.

10 En 'skrabet' æstetik præger typisk tv-reportagen, idet tv-holdet, når det rykker ud for eksempelvis at dække historien om en ildebrand, ikke har tid til at skabe korrekt belysning, bruge stationært kamera mv. Ved reportagen er selve ildebranden dét drama, som skaber indlevelse hos tilskueren, hvorfor denne 'ser gennem fingre med' den 'skrabede' æstetik. Dette princip synes Trier at have overført på sine film i de seneste to trilogier.

11 Man kan se den naive og den kritiske læser i forhold til f.eks. Harry Potter bøgerne/filmene, hvor barnet ofte vil være den naive læser, mens den voksne udgør den kritiske. Man kan også kalde dette for en 'dobbeltadressat'.

12 Se Heidi Jørgensen [Philipsen]: »Nye dansk don't feel good-film: Et interview med Annette K. Olesen« in 16: 9 (april 2004) http://www.16-9.dk/2004-04/pdf/169 april2004_side06_annetteolesen.pdf

13 Der anvendes naturlige historier i scener, hvor mand og kvinde mødes, måden de går ud og ind af døre på, måden de spiser mad på mv., og disse medvirker til at skabe genkendelighed. Mens det skandaløse lurer f.eks. i scener, hvor genkendeligheden pludselig afbrydes af manden, der pinagtigt falder ned af trappen i Reconstruction, eller Charlotte der overraskende yder førstehjælp til Veronica/Ulrik i En soap. 